\title{
Assessment in Spanish heritage language programs
}

\author{
Clara Burgo ${ }^{1}$ \\ Loyola University Chicago \\ Department of Modern Languages and Literatures Crown Center 217B
}

ABSTRACT

Spanish heritage language learners (HLLs) are heterogeneous in nature. Thus, how can we assess these students? Most of the literature on this has been on placement exams (Polinsky \& Kagan, 2017, among others), but the focus of this article is on assessment in Spanish heritage courses. Placement test results should be indicators of what should be included in the curriculum. One of the main challenges is the lack of the following components: specific proficiency indicators for HLLs, consensus in defining key concepts, understanding dialect variation, assessment for measuring linguistic skills, and finally research on HLLs' assessment (Malone, Kreeft Peyton, \& Kim, 2014). Thus, assessment is the biggest challenge in HL education due to the dominant monolingual ideologies, so formative assessment practices are recommended to confront them by allowing HLLs to negotiate their linguistic identities via multilingual perspectives (King, Liu, \& Schwedhelm, 2018). What are specific tools or activities to negotiate these? Personal narratives of US Latinx were collected by Carreira and Beeman (2014) for the sake of reflections of HLLs. GonzálezDavies $(2004,2018)$ also mentions the importance of peer-to-peer strategies for translation competence. These projects can also become group projects, like the manifestos implemented by Moreno and MacGregor-Mendoza (2019) in a course in which language, culture, and community are the goals. All these activities are examples of the kinds of assessment that may be effective in the heritage classroom and may guide their instructors. The goal of this article is to suggest activities to connect HLLs with their communities at the same time that their learning gains are assessed in terms of language proficiency.

Keywords: assessment, language proficiency, personal narratives.

\section{RESUMEN}

Los aprendices como lengua de herencia (ALH) de español son heterogéneos en naturaleza. Por tanto, ¿cómo podemos evaluar a estos estudiantes? La mayoría de la literatura sobre esto ha sido sobre exámenes de ubicación (Polinsky \& Kagan, 2017, entre otros), pero el enfoque de este artículo está en la evaluación en los cursos de herencia de español. Los resultados de los exámenes de ubicación deberían ser los indicadores de lo que se debería incluir en el currículo. Uno de los mayores retos es la falta de los siguientes componentes: indicadores de proficiencia específicos a los ALH, consenso al definir conceptos clave, comprender la variación dialectal, evaluación para medir habilidades lingüísticas, y finalmente investigación en la evaluación de los ALH (Malone, Kreeft Peyton, \& Kim, 2014). Por tanto, la evaluación es el mayor reto en la educación como LH debido a las ideologías monolingües dominantes, así que se recomiendan prácticas de evaluación formativa para confrontarlas permitiendo a los ALH negociar sus identidades lingüísticas vía perspectivas multilingües (King, Liu, \& Schwedhelm, 2018). ¿Cuáles son las herramientas o actividades especifícas para regular estas? Se recogieron las narrativas personales de los latinx de EEUU por Carreira and Beeman (2014) en busca de reflexiones de los ALH. González-Davies $(2004,2018)$ también menciona la importancia de estrategias de compañero a compañero para la competencia de la traducción. Estos proyectos pueden además convertirse en proyectos de grupo, como los manifiestos implementados por Moreno and MacGregor-Mendoza (2019) en un curso en cuya lengua, cultura y comunidad son los objetivos. Todas estas actividades son ejemplos de los tipos de evaluación que podrían ser efectivos en el aula de herencia y podrían 
guiar a los instructores. El fin de este artículo es sugerir actividades para conectar a los ALH con sus comunidades a la vez que su aprendizaje se evalúa en términos de proficiencia lingüística.

Palabras clave: evaluación, competencia lingüística, narrativas personales.

\section{Introduction}

It is well known that Spanish heritage language learners (HLLs) are very heterogeneous in nature, and many institutions do not have the funding or the student population to offer courses at different levels, so they may only offer one course at the basic or intermediate level. Thus, how can we assess these students under these circumstances? There is not much literature on this besides placement exams (Polinsky \& Kagan, 2017, among others), but the focus of this article is on the assessment in Spanish heritage courses themselves. What are the main purposes of assessment in the heritage language (HL) context? According to Carless (2012), they are to promote and judge student learning, and to provide accountability. The first one responds to formative assessment and the next two to summative assessment. The formative assessment was called by Carreira (2012) "assessment for learning". Instructors are able to monitor students' progress and if goals have been achieved (Beaudrie, Ducar, \& Potowski, 2014).

Placement test results may be used as indicators of what should be included in the curriculum. In fact, sometimes they show surprising results contrary to instructors' and students' perceptions. In Petrovic (2018), HLLs of Croatian in Canada self-assessed their linguistic skills in their HL and in English, and they only considered their listening skills to be as strong in Croatian as in English, contrary to the way they assessed their other skills, where they considered writing to be their weakest skill. This is usually the trend in second generation HLLs. Nevertheless, as Kagan and Kudyma (2019) argue, there are no studies so far on listening and reading proficiency of HLLs. As they say, we just assume that listening is their strongest skill. However, as Kagan and Dillon (2009) show, listening comprehension is not as strong as believed. Thus, these researchers suggest giving more weight to this skill in the curriculum. In other studies, such as Valentín-Rivera (2018), HLLs were very accurate regarding their self-perception of their limitation in specific skills, except in one aspect: their limited lexicon. She found that their poor mechanical skills may influence their limited lexicon domain. On the other hand, these learners turned out to be fluid writers that approach the text randomly without following a strategic plan. Thus, it is essential to guide them in the writing process to empower them in the heritage classroom. In fact, Elola (2017) highlights that most studies on HLLs' writing do not address instructional methods. ValentínRivera (2015) found that HLLs benefited more than L2 learners from implicit or explicit instruction and feedback regarding aspectual distinction. Elola (2017) argues that traditionally instruction has been assessed considering linguistic gains, but this would not be very effective in the case of HLLs if we take writing as a complex task. As a consequence, she suggests the use of more holistic approaches. We must bear in mind the idea that authentic language should be encouraged to acknowledge linguistic variation.

Minor (2017) offers some specific useful guidance for instructors such as targeting the most common errors and adapting materials accordingly. This holistic approach should be followed by formative assessments throughout the course to make changes in the curriculum. Formative assessment is especially beneficial for HLLs so that they can acquire the metalinguistic awareness they lack due to the fact that they are naturalistic learners (Carreira, 2012). On top of this, Carreira highlights the fact that formative assessment takes into consideration students' motivation and feelings. Through this assessment, students get continuous guidance and feedback as well as practice. Ultimately, there should be a proficiency assessment following the ACTFL guidelines (Titus, 2012). 


\section{Challenges for proficiency assessment}

One of the main challenges in terms of proficiency assessment is the lack of the following components: specific proficiency for HLLs, consensus in defining key concepts, understanding dialect variation, assessment for measuring linguistic skills, and research on HLLs' assessment, especially on less commonly taught languages (Malone, Kreeft Peyton, \& Kim, 2014). Bilingualism needs to be seen as a dynamic construct and proficiency has to be observed from a multilingual perspective through which code-switching is a common practice (García, 2009). Thus, assessment is the biggest challenge in HL education due to the dominant monolingual ideologies, so formative assessment practices are recommended to allow HLLs to negotiate their linguistic identities via multilingual perspectives as mentioned above (King, Liu, \& Schwedhelm, 2018).

When it comes to assessment, we should distinguish between:

a) placement procedures (e.g. placement exams, background questionnaires, interviews)

b) classroom assessment

This article intends to focus on the second component: classroom assessment. What are specific tools for classroom assessment?

\section{Suggestions for HLLs' assessment}

Malone, Kreeft Peyton, and Kim (2014) proposed creating a HL framework with standards for proficiency so that we can measure it with reliable and valid tools. Beaudrie, Ducar, and Potowski (2014) called for a sociolinguistically-informed approach with differentiated assessment that goes along with differentiated instruction due to the heterogeneity of HLLs. Mercado (2000) suggested the use of portfolios, rubrics, classroom observations, or personal narratives, among other tools. In the same vein, Carreira (2012) advocated for a formative assessment with continuous feedback for students and instructors to track their progress. Examples of these are reflection journals, self or peer assessments, and exit cards. The aim is to monitor students' progress to predict whether their needs are met. Using the same assessment tools that we do for L2 learners may not work for several reasons, but especially those that assess metalinguistic knowledge and the domain of standard forms (Beaudrie, 2016). Thus, this researcher suggests the use of authentic assessment based on performance-based measures so that HLLs can show what they can do in the target language. It is necessary to develop specific standards for HLLs' proficiency in speaking, writing, reading, and listening.

On the other hand, project-based learning is indeed an efficient way to have HLLs work on a task that addresses a real-world need through authentic input that will allow them to produce good output (Carreira, Hitchins Chik, \& Karapetian, 2019). A good technique is the use of a teaching and learning cycle (Rose \& Martin, 2012). Gómez Pereira (2018) used biographies in her study of HLLs' writing as an academic genre to discuss biographies of Latinx around the world, starting with students' families. Functional text analyses were used as an assessment tool (Schleppegrell, 2006). The content of these biographies was assessed by examining their linguistic choices regarding verbs and if the writing was focused on the main character. The results of this study showed the advantages of unfolding meaning and how this helped with the quality of students' writing. On top of this, they were given the opportunity to disclose multiple identities in the classroom. Loureiro-Rodríguez (2013) recommended a meaningful writing approach to encourage production and self-reflection. She made a distinction between online discussions and compositions. The former were on a topic related to their Spanish use, and the latter were linguistic autobiographies. This approach and the tasks used by the instructor allowed 
her to get to know her students and to adapt the curriculum according to their needs. Students were able to feel part of a community and observe all that they had in common.

In terms of oral assessment, another language assessment tool for emergent bilinguals is the oral narrative retelling, as explained in Lucero (2016). Additionally, there is some research on the use of OPIs with HLLs. Nik (2012) compared Hindi HLLs' and L2 learners' oral skills. HLLs were perceived as native-like and they spoke faster. The problem arose when they were rated. They were rated higher on the interactive tasks than on their presentational tasks. Additionally, as Beaudrie, Ducar, and Potowski (2014) explained, another problem was HLLs' use of English whenever they lacked mastery of their HL. This exam proved to be an ambiguous measure of language proficiency for HLLs. Therefore, Nik (2012) suggested that the OPI manual address these issues by stating what is expected for HLLs and that the ACTFL guidelines accommodate these students. Another study on the use of the OPI to assess HLLs was that of Martin, Swender, and Rivera-Martinez (2013). They wanted to explain why HLLs did not achieve a higher performance. The HLLs in their study overestimated their oral abilities because they were fluent in their HL, so they did not see the need for instruction. These two studies suggest pedagogical implications so that these learners understand the importance of instruction to expand their vocabulary and raise their awareness about formality, and to develop skills especially in the presentational mode.

On the other hand, Oh and $\mathrm{Au}$ (2005) conducted a language assessment based on the following components: accent assessment (narrative and phonemes) and grammar assessment (narrative and grammaticality judgments). The participants in this study ranked in the middle in every category on average and with $70 \%$ accuracy in grammaticality judgments. HLLs who had a strong identity link with the Latinx culture and who were involved in the culture and interacted with people in the community had a more native-like accent. According to this study, these factors did not have an impact on their grammar though. Faltis (1984) studied the perceptions of instructors and students in their reading and writing in Spanish. Most of the assignments were on academic subjects and instructors gave more importance to reading than writing. It would be interesting to determine if the fact that HLLs tend to have less command of reading than writing is a factor. It is evident that HLLs need to be exposed to different genres and types of texts (Potowski, 2005). In the same vein, Hislope (2003) found that HLLs mainly read entertainment literature in Spanish, so she suggested to start with that genre and gradually move towards other academic texts. Rodrigo (2013) also argued that students need to be exposed not only to a variety of texts, but the quantity is also relevant due to the importance of this kind of input for language acquisition.

On another note, through a cognitive-oriented approach, Mikulski and Elola (2011) assessed the writing of HLLs in an advanced intermediate Spanish course. These learners spent plenty of time on planning in Spanish. As Beaudrie, Ducar, and Potowski (2014) claimed, assessing writing is very challenging because there are not specific standards for HLLs. These researchers suggested two principles of assessment for the HL classroom: to make it highly meaningful and to differentiate assessment to provide students with multiple opportunities to show progress.

Using a variety of assessment tools would be ideal in informing HLLs' teaching: convergent and divergent assessment. As Carreira (2012) explains, examples of convergent assessment are can-do statements and closed questions, and examples of divergent assessment are open-ended questions. Poehner (2008), on the other hand, made a distinction between static and dynamic assessment. Static assessment consists of isolating discrete traits that can be measured, and dynamic assessment focuses on understanding the development.

Computerized learning has also been considered key for success (Luo, $\mathrm{Li}, \& \mathrm{Li}, 2019)$. In their study of a Chinese heritage program, they found that students worked better and faster using learner-centered online materials and 
engaging in multimedia projects. Regarding multimedia projects, Belpoliti and Gironzetti (2017) implemented the design of a digital family scrapbook, an oral interview report, or at a more advanced level, a digital storytelling and an oral academic presentation. Multimodality has also been proven to be efficient in the heritage classroom. Karahisardilis and Young (2017) conducted a study to examine the role of multimodality in increasing oral language proficiency of Spanish HLLs. The diverse nature of the tasks elicited communicative strategies that suggested language growth. Henshaw (2016) made a comparison between a traditional composition course for L2 learners and an equivalent online course for HLLs. As for assessment, the heritage course mainly consisted of online assignments including interactive tutorials and self- reflections on the composition drafts' feedback in an online journal.

As the National Forum on Assessment in October of 1995 stated, there should be some principles that connect assessment and learning, such as assessment should support student learning, it should be fair and require the collaboration of educators and student communities, and it should be updated to make sure it is beneficial.

\section{The role of culture}

Culture must play a crucial role in assessment. Beaudrie, Ducar, and Relaño-Pastor (2009) assessed the extent to which heritage courses were meeting students' needs regarding culture and identity. The instructors of these courses were very sensitive about intra-cultural awareness, and encouraged students to learn more about their heritage culture comparing it to other Latinx cultures. This study showed the importance of the role of culture in the curriculum and of promoting self-identity and cultural pride. However, little work has been done to analyze the role of the personal essay for advanced literacy. As Reznicek- Parrado (2014) argued, advanced literacy should be envisioned as a social tool that incorporates HLLs' voices.

What is the role of culture? Brownlow (2013) used supplementary readings with cultural topics to increase reading proficiency in Spanish HLLs and implemented reading clubs so that students could collaborate and focus on cultural topics. Initially, they conducted a self-assessment about their background, then there was a summative and formative assessment, a survey and a teacher journal. This teacher journal was a way for the instructor to document instances when HLLs were looking for readings in Spanish to read after class. Brownlow (2013) found that those who took part in the reading clubs increased their reading comprehension. Writing and reading tend to be deeply connected so this is a good example since the reading clubs addressed writing. In fact, Grabe (2009) offered several recommendations on assessing reading: encouraging students to read longer texts, background knowledge presented in a positive way, group tasks for discussions, assessing skills such as synthesizing or evaluating, among others.

\section{HLLs' self-assessment}

Research shows that most HLLs self-assessed their literacy skills at an intermediate level or less, and almost half of them self-assessed listening and mainly speaking at that level too (Carreira \& Kagan, 2011). In fact, they tend to over-assess their proficiency, as found in Martin, Swendler, and Rivera- Martinez (2013) regarding the oral proficiency of Spanish and Russian HLLs. These data may make us question their ability to assess themselves and consequently not consider this an appropriate tool for placement. In this vein, Carreira (2014) claimed that HL programs tend to offer courses at high proficiency levels. Thus, we may expect that some of these HLLs are not accurately placed in the right course, possibly negatively affecting their self-assessment. 
As Beaudrie (2018) claimed, acquiring literacy skills is one of the main goals of HL education. In a study conducted by Yi (2008) with Korean HLLs, they recorded their daily voluntary writing activities. Instant messaging was the most frequent one out of the diverse kinds of activities they engaged in. There were multiple benefits of implementing this strategy, such as increasing their motivation to write, since they found it more enjoyable. As a consequence, they showed more confidence and fluency in the HL. This study, additionally, suggests that peer interaction is an important component for these learners' literacy development. This way, students learn more about both their cultural heritage and literacy.

Another example of self-assessment for HLLs are the activities that are developed in study-abroad programs. That is, in the Russian Flagship study-abroad program, HLLs underscored the significance of the internships and field trips (Carreira, 2013). In service-learning courses, the self-assessment usually includes surveys, the writing of reflections, blogs, and/or journals. It is crucial not to forget that we should assess learning and not service (Howard, 2001). There is also the suggestion of including a personal digital storytelling project for personal and sociolinguistic gains (Martínez \& Martín, 2018). As Lear and Abbott (2009) state, guided reflections enhance student learning and give the instructor the chance to clarify and help the student as needed.

Personal narratives of US Latinx were collected by Carreira and Beeman (2014) for the sake of reflections of HLLs as language brokers. In the meantime, instructors can engage in interpreting tasks that reflect these brokering tasks, as suggested in Mellinger and Gasca-Jiménez (2019). González-Davies (2004, 2018) also mentions the importance of peer-to-peer strategies for translation competence. These projects can also become group projects (instead of individual reflections), like the manifestos implemented by Moreno and MacGregorMendoza (2019) in a composition course in which language, culture, and community were the goal. The topics were related to both their service and class discussions, and students were provided with the opportunity to discuss controversial topics in a safe environment. This project made students express their thoughts, but also encouraged them to work on a plan of action by presenting problems and solutions. The interest that this project sparked in these students led them to the creation of childhood tales (cuentos infantiles). These tales created a strong relationship between the community and their classroom, and taught them the importance and value of the community and of acquiring academic Spanish skills when creating these tales.

Collaborative service-learning is also a good strategy to fight linguistic insecurity through teamwork. An example of this is the oral history project. In DuBord and Kimball (2016), the students received training on conducting interviews, and worked in groups to create questions. They also received training on interviewing in Spanish and English. In terms of assessment, their writing was assessed in the form of reflective essays and a portfolio essay. These authors argued that this inclusive local project and critical assessment of student learning goals in community-based learning can promote partnerships that will help these students build on their strengths. Through ethnography and an oral history project, Foulis and Barajas (2019) fostered the improvement of their HLLs' writing skills at the same time that they acknowledge the value of their own stories. Students were given the opportunity to be agents in the creation of knowledge and to establish a sense of community.

Ruggiero (2017) conducted a study based on the CruCES project, a service-learning opportunity to create community in a diverse neighborhood through micro-economy projects with two local non-profit organizations. Students also participated in a study on intercultural sensitivity, which is innovative in service-learning projects with HLLs. Intercultural sensitivity development was assessed via reflection journals (digital storytelling and reflections) and surveys. Reflection journals were intended to identify areas of development. Thus, they should be tailored to students' needs. Findings showed learning gains in intercultural sensitivity, positive attitudes towards the community, and an increase in their self-confidence and self-esteem. 


\section{Conclusions}

This article attempts to present an overview of the current situation of Spanish HLLs' courses and programs in terms of assessment. It seems that there is a general agreement that more rigorous assessment tools are still needed to foster literacy, despite some efforts to assess HLLs accurately, such as the use of formative assessment by Carreira (2012) to monitor student work by providing guidance and feedback. HLLs' self-assessments are unfortunately common in terms of placement, but they may be problematic since these students tend to overassess themselves at higher levels of proficiency. Furthermore, the fact that some programs are small and do not usually offer courses at all proficiency levels may have an impact on the wrong placement of some of these learners.

Due to the fact that there are many other challenges such as the lack of studies on assessment and the lack of proficiency measures, an overview of specific tasks that have been successfully used in the HL classroom have been presented, such as personal narratives, reflections, peer-to-peer strategies for translation competence, group projects like manifestos, or service-learning projects such as oral history or digital storytelling. The goal of these projects is to connect HLLs with their communities as well as to assess their learning gains in terms of language proficiency. Finally, this article attempted to present effective activities to assess HLLs' learning gains and to connect them with their communities.

\section{Declaration of conflicting interests}

The author(s) declared no potential conflicts of interest with respect to the research, authorship, and/or publication of this article.

\section{Funding}

The author(s) received no financial support for the research, authorship, and/or publication of this article.

\section{About the author}

Dr. Clara Burgo is an Associate Professor of Spanish at Loyola University Chicago. Her research and teaching interests are Spanish for Heritage Speakers and Sociolinguistics.

\section{Acknowledgements}

I would like to thank the reviewers for their insightful comments and feedback. A special thanks to my dear friend and colleague, Janine Matts, for her unconditional support. 


\section{References}

Beaudrie, S. (2016). Advances in Spanish heritage language assessment: Research and instructional considerations. In Pascual y Cabo, D. (Ed.), Advances in Spanish as a heritage language, (pp. 143-158). Amsterdam, Netherlands: John Benjamins.

Beaudrie, S. (2018). On the relationship between self-concept and literacy development in the Spanish heritage language context. Reading \& Writing Quarterly, 34(2), 147-159.

Beaudrie, S., Ducar, C, \& Potowski, K. (2014). Heritage language teaching: Research and practice: Columbus, OH: McGraw-Hill Education.

Beaudrie, S., Ducar, C., \& Relaño-Pastor, A. (2009). Curricular perspectives in the heritage language context: Assessing culture and identity. Language, Culture and Curriculum, 22, 157-174.

Belpoliti, F., \& Gironzetti, E. (2017). Metaknowledge and metalinguistic strategies in the Spanish for heritage learners classroom: a curriculum redesign. Hispanic Studies Review, 2(1), 45-72.

Brownlow, G. (2013). The Effects of Supplementary Reading Activities for Spanish Heritage Learners. Retrieved from Sophia, the St. Catherine University repository website: http://sophia.stkate.edu/cgi/viewcontent.cgi?article=1024\&context=maed.

Carless, D. (2012). From testing to productive student learning: Implementing formative assessment in Confucian-heritage settings. New York: Routledge.

Carreira, M. (2012). Formative assessment in HL teaching: purposes, procedures, and practices. Heritage Language Journal, 9(1), 100120.

Carreira, M. (2013). Advanced proficiency: A practitioner's perspective on this special issue. Heritage Language Journal, 10(2), 139152.

Carreira, M. (2014). Teaching heritage language learners: A study of programme profiles, practices and needs. In Trifonas, P.P., Aravossitas, T. (Eds.), Rethinking Heritage Language Education (pp.20-44). Cambridge, UK: Cambridge University Press.

Carreira, M., \& Beeman, T. (2014). Voces: Latino Students on Life in the United States. Santa Barbara, CA: Praeger.

Carreira, M., \& Kagan, O. (2011). Results of the National Heritage Language Survey: Implications for teaching, curriculum design, and professional development. Foreign Language Annals, 44, 40-64. doi:10.1111/j.1944- 9720.2010.01118.x

Carreira, M., Hitchins Chik, C., \& Karapetian, S. (2019). Project-based learning in the context of teaching heritage language learners . In Gras-Velazquez, A. (Ed.), Project-Based Learning in Second Language Acquisition: Building Communities of Practice in Higher Education (pp. 135- 152). New York, NY: Routledge.

DuBord, E., \& Kimball, E. (2016). Cross-language community engagement: Assessing the strengths of heritage learners. Heritage Language Journal, 13(3), 298- 330.

Elola, I. (2017). Writing in Spanish as a second and heritage language: Past, present, and future. Hispania, 100(5), $119-124$.

Faltis, C. J. (1984). Reading and writing in Spanish for bilingual college students: What's taught at school and what's used in the community. Bilingual Review / La Revista Bilingüe, 11(1), 21-32.

Foulis, E., \& Barajas, J. (2019). Weaving our histories: Latin@ ethnography in the heritage language classroom. Journal of Folklore and Education, 6, 98- 107.

García, O. (2009). Bilingual Education in the 21st Century: A Global Perspective. Chichester: John Wiley \& Sons.

Gómez-Pereira, D. (2018). Developing academic writing and cultural identity for Spanish heritage language learners (HLLs) through writing texts in Spanish. (Doctoral Dissertation). Retrieved from Proquest Dissertation Publishing.

González-Davies, M. (2004). Multiple Voices in the Translation Classroom: Activities, Tasks, and Projects. Amsterdam, Netherlands: John Benjamins.

González-Davies, M. (2018). The use of translation in an integrated plurilingual approach to language learning: Teacher strategies and best practices. Journal of Spanish Language Teaching, 4(2), 1-12.

Grabe, W. (2009). Teaching and testing reading comprehension. In M. Long \& C. Doughty (Eds.), Handbook of second and foreign language teaching (pp. 441-462). Malden, MA: Blackwell.

Henshaw, F. (2016). Online courses for heritage learners: Best practices and lessons learners. In Pascual y Cabo, D. (Ed.), Advances in Spanish as a heritage language, (pp. 281-298). Amsterdam, Netherlands: John Benjamins. 
Hislope, K. (2003). A reading study of Spanish heritage speakers. The Reading Matrix, 3(2), 1-21.

Howard, J. (2001). Service-learning course design workbook (Michigan Journal of Community Service Learning, Companion Volume). University of Michigan: OCSL Press.

Kagan, O., \& Dillon, K. (2009). The professional development of teachers of heritage language learners: A matrix. In M. Anderson \& A. Lazaraton (Eds.), Bridging context, making connec- tions: Selected papers from the fifth international conference on language teacher education (pp. 155-175). Minneapolis, MN: Center for Advanced Research on Language Acquisition.

Kagan, O., \& Kudyma, A. (2019). Assessment and curriculum for heritage language learners: Exploring Russian data. In P. Winke, S. M. Gass (eds.), Foreign Language Proficiency in Higher Education, Educational Linguistics 37, (pp. 71-92). Springer Nature Switzerland AG.

Karahisarlidis, C., \& Young, A. (2017). Spanish oral language proficiency assessments and two-way immersion heritage language learners: Multimodal language analysis. Hispanic Studies Review, 2(1), 73-85.

King, K.A., Liu, M., \& Schwedhelm, M.C. (2018). Language policy, language study, and heritage language education in the US. In A. Bonnet \& P. Siemund (Eds.), Foreign Language Education in Multilingual Settings (pp. 77-98). John Benjamins.

Lear, D., \& Abbott, A. (2009). Aligning expectations for mutually beneficial community service-learning: The case of Spanish language proficiency, cultural knowledge, and professional skills. Hispania, 92, 312-323.

Loureiro-Rodríguez, V. (2013). Meaningful writing in the heritage language class: A case study of heritage learners of Spanish in Canada. L2 Journal, 5(1), 43-58.

Lucero, A. (2016). Oral narrative retelling among emergent bilinguals in a dual language immersion program. International Journal of Bilingual Education and Biligualism, DOI: 10.1080/13670050.2016.1165181

Luo, H., Li, Y., \& Li, M.Y. (2019). Heritage language education in the United States: A national survey of college-level Chinese language programs. Foreign Language Annals, 52(1), 101-120.

Malone, M.E., Kreeft Peyton, J., Kim, K. (2014). Assessment of heritage language learners: Issues and directions. In T. G. Wiley, J. Kreeft Peyton, D. Christian, S. C. K. Moore, \& N. Liu (Eds.), Handbook of Heritage, Community, and Native American Languages in the United States Research, Policy, and Educational Practice, (pp. 349-358). New York, NY:: Routledge.

Martin, C., Swender, E., \& Rivera-Martinez, M. (2013). Assessing the oral proficiency of heritage speakers according to the "ACTFL Proficiency Guidelines 2012- Speaking." Heritage Language Journal, 10(2), 73-87.

Martínez, G. \& San Martín, K. (2018). Language and power in a medical Spanish for heritage learners program: A learning by design perspective. In G. C. Zapata \& M. Lacorte (Eds.), Multiliteracies Pedagogy and Language Learning: Teaching Spanish to Heritage Speakers (pp. 107-128). New York, NY: Palgrave Macmillan.

Mellinger, C., \& Gasca Jiménez, L. (2019). Challenges and opportunities for heritage language learners in interpreting courses in the U.S. context/ Retos y oportunidades para hablantes de lenguas de herencia en cursos de interpretación en el contexto estadounidense. Revista Signos. Estudios de Lingüística, 52(101), 950-974.

Mercado, C.I. (2000). Monitoring the progress of heritage language learners: Assessment trends and emerging practices. In J.B. Webb \& B.L. Miller (Eds.), Teaching heritage language learners: Voices from the classroom (pp. 209-230). Yonkers, NJ: American Council on the Teaching of Foreign Languages.

Mikulski, A., \& Elola, I. (2011). Spanish heritage language learners' allocation of time to writing processes in English and Spanish. Hispania, 94(4), 715-733.

Minor, D. (2017). Language instruction in the expanding borderlands teaching heritage language learners enrolled in L2 classrooms. The Journal of the Midwest Modern Language Association, 50(2), 149-179.

Moreno, G., \& MacGregor-Mendoza, P. (2019). Language, culture, and service: Innovative strategies for bridging SHL classrooms and communities through service-learning. In G. Thompson, \& S.M. Alvord (Eds.), Contact, Community, and Connections: Current Approaches to Spanish in Multilingual Populations (pp. 277-304). Wilmington, DL: Vernon Press.

Nick, G. (2012). Hindi heritage language learners' performance during OPIs. Characteristics and pedagogical implications. Heritage Language Journal, 9(2), 18-36.

Oh, J., \& Au, T. (2005). Learning Spanish as a heritage language: The role of sociocultural background variables. Language, Culture and Curriculum, 18(3), 229-241. DOI:10.1080/07908310508668744

Petrovic, I. (2018). Croatian as a heritage language in Canada. Zbornik Radova Filozofskog Fakulteta u Splitu, 11, 59-72. 
Poehner, M. E. (2008). Dynamic assessment: A Vygotskian approach to understanding and promoting second language development. Berlin: Springer.

Polinsky, M., \& Kagan, O. (2007). Heritage languages: In the 'wild' and in the classroom. Compass of Language and Linguistics, 1(5), 368-395.

Potowski, K. (2005). Fundamentos de la enseñanza del español a hispanohablantes en los EE.UU. Madrid: Arco Libros.

Reznicek-Parrado, L.M. (2014). The personal essay and academic writing proficiency in Spanish heritage language development. Arizona Working Papers in SLA \& Teaching, 21, 71-83.

Rodrigo, V. (2013). Situación lingüística de los hablantes de herencia en Estados Unidos y la mejora de su competencia en español. In B. Blecua, S. Borrell, B. Crous, \& F. Sierra. (Eds.), Plurilingüismo y enseñanza de ELE en contextos multiculturales. (pp. 748757). University of Girona Press.

Rose, D., \& Martin, J. R. (2012). Learning to Write, Reading to Learn: genre, knowledge and pedagogy in the Sydney school. London: Equinox.

Ruggiero, D.M. (2017). The CruCES project: A consideration of service learning and intercultural sensitivity among heritage learners. Revista de Lenguas para Fines Especificos, 23(1), 45-62.

Schleppegrell, M. (2006). The linguistic features of advanced language use: the grammar of exposition. In H. Byrnes (Ed.), Advanced Language Learning: The contribution of Halliday and Vygotsky (pp. 134-146). London and New York: Continuum.

Titus, J. (2012). Creating an online assessment test for heritage learners of Russian. Heritage Language Journal, 9(2), $222-244$.

Valentín Rivera, L.E. (2015). Collaborative narratives between Spanish heritage and foreign language Learners: Understanding aspect selection through two types of corrective feedback. (Unpublished Doctoral Dissertation). Texas Tech University, TX.

Valentín Rivera, L.E. (2018). Comparing the self-perceptions and efficacy of Spanish heritage language learners as authors: In search of an effective writing process. Estudios de Lingüística Aplicada, 68, 99-130. doi: 10.22201/enallt.01852647p.2018.68.743

Yi, Youngjoo. (2008). Voluntary writing in the heritage language: A study of biliterate Korean-heritage adolescents in the US. Heritage Language Journal, 6(2), 72- 93. 